Brit. F. vener. Dis. (1974) 50, 334

\title{
Specificity, sensitivity, and diagnostic value of the TPHA test
}

\author{
J. LESIŃ SKI, J. KRACH, AND E. KADZIEWICZ \\ Central Laboratory, Departmental Polyclinic of Dermatology and Venereology, Bialystok, Poland
}

The Treponema pallidum haemagglutination test (TPHA) was first described by Rathlev (1965). The investigations made by Tomizawa and Kasamatsu (1966) and Tomizawa, Kasamatsu, and Yamaya (1969), who introduced an absorbing reagent to remove cross-reacting antibodies, resulted in an improvement of this method and the production of standard antigen and other reagents necessary for the test. The reagents used by almost all these authors were manufactured in the Fuji Zoki Laboratories, Tokyo, Japan. The studies of Cox, Logan, and Norins (1969) led to the development of an automated microhaemagglutination assay (AMHA-TP).

The problem of specificity of the TPHA test cannot yet be regarded as finally solved. It would seem from the results of the investigations of Logan and Cox (1970), Paris-Hamelin, Catalan, and Vaisman (1970), Lesiński and Krach-Karczmarczyk (1971), Dixon, Grocholski, and Kadis (1972), Manikowska-Lesińska (1973a), and Kraft, Morgenstern, Raff, and Söltz-Szöts (1973) that the TPHA test approximates in specificity to the FTA-ABS test. The studies of West and Pagano (1972), Garner, Backhouse, Daskalopoulos, and Walsh (1972), Johnston (1972), Kraft and others (1973), Sequeira and Eldridge (1973), and O'Neill, Warner, and Nicol (1973) have established that the TPHA test is very rarely positive in presumed normal sera and relatively rarely in BFP reactors. The more recent investigations of Garner, Backhouse, Daskalopoulos, and Walsh (1973), however, show that the specificity of the TPHA test can be considerably lower than that of the FTA-ABS test. They reported that 2 to 17 per cent. of TPI-negative leprosy sera and sera from selected groups of BFP reactors were also positive in the TPHA test.

There is, on the whole, agreement in the results so far published regarding the sensitivity of the TPHA test. Logan and Cox (1970), Le Clair (1971),

Received for publication January 7, 1974
Lesiński and Krach-Karczmarczyk (1973a), O’Neill and others (1973), and Johnston (1972) have established that the TPHA test is highly sensitive and, with the exception of early cases of primary syphilis, has a sensitivity practically equal to that of the FTA-ABS test. Only Luger and Spendlingwimmer (1973) have reported that its sensitivity is greater than that of the FTA-ABS test in all stages of syphilis.

The TPHA test has undeniable advantages in the comparative ease with which it is performed and read, and the fact that all the necessary reagents can be standardized, manufactured, and made available commercially. These advantages, together with the prospect of further automation of this method, will considerably facilitate its wide application. Dixon and others (1972), O'Neill and others (1973), Luger and Spendlingwimmer (1973), and Sequeira and Eldridge (1973) consider it suitable as a qualitative screening test for syphilis and other treponematoses. Lesiński and Krach-Karczmarczyk (1971, 1973a,b) have shown that it is particularly valuable in the diagnosis of cases of late syphilis. The results of Manikowska-Lesińska (1973a,b) suggest that the TPHA test result is an important criterion in the serological verification of problem sera, especially in cases in which the results of the TPI and FTA-ABS tests disagree.

The aim of our investigations was to evaluate the results of the TPHA test in presumed healthy persons, in BFP reactors, in a group of so-called problem sera, and in patients in various stages of syphilis. We also wished to establish more precisely the limits of the diagnostic value of this new treponemal test.

\section{Material}

1,400 sera were investigated, of which 470 were from patients definitely diagnosed as having syphilis, 600 from presumed healthy persons, and 130 from presumed biological false positive reactors. We also investigated a group of 200 so-called problem sera. 
Sera from presumed healthy persons (600)

Seventy sera were from school-girls (aged 16 to 18 years), 150 from male conscripts from rural areas (aged 19 to 20 years), 140 from married pregnant women, 140 from school-teachers (men and women aged 25 to 60 years), and 100 from married hospitalized patients over 50 years of age. In these groups of the population the risk of infection is very low.

Sera from presumed biological false positive reactors (130) These 130 sera were selected because in previous screening procedures they gave reactive or weakly reactive reagin tests not confirmed by TPI and FTA-ABS tests.

Sera from untreated syphilitics (270)

140 sera were from patients with early syphilis and 130 from patients with late syphilis. The large majority of late syphilitics, especially those with latent syphilis, were very long standing cases, detected serologically on hospital admission.

\section{Sera from treated syphilitics (200)}

In this group there were 100 sera from patients treated for early syphilis, ninety from patients treated in the late stage of syphilis, and ten from persons followed up after prophylactic treatment given during the incubation period.

The patients treated for primary syphilis (predominantly VDRL-positive) were examined 12 to 18 months after treatment, those with secondary syphilis 1 to 3 years after treatment and the patients with early latent syphilis, 3 years after treatment.

The patients with late syphilis were tested, at the earliest, 5 years after treatment, the majority being tested 10 to 30 years after treatment.

The patients who had received prophylactic treatment were tested 3 to 6 months after treatment. At the beginning of this treatment all these patients had no clinical signs of syphilis and were FTA-ABS and VDRL negative. All the persons admitted that they had had sexual relations with a person suffering from early syphilis not less than 4 weeks before beginning prophylactic treatment.

Problem sera (200)

This group consisted of 200 sera with disagreement between the TPI and FTA-ABS results or with doubtful TPI or borderline FTA-ABS results.

\section{Methods}

The TPHA test was carried out on the first 100 patients with standard antigens according to the macro-method described by Tomizawa and Kasamatsu (1966). The remaining sera were tested by the manual micro-method, based on the modification of Cox and others (1969). The reagents used in both TPHA modifications were manufactured in the Fuji Zoki Laboratories. The results of both these methods were practically identical. The sera were tested at a dilution of $1 / 80$. Some of the doubtful results or those difficult to interpret were repeated at a dilution of $1 / 40$ or $1 / 160$.
TPI, VDRL, FTA, and FTA-ABS tests were carried out according to the description in the Polish manual "Modern Syphilology" (edited by Lesiński, Miedzinski, and Towpik (1970). These methods differ only slightly from the methods described in the USPHS "Manual of Tests for Syphilis" (1964, 1969). The only significant difference is in the method of absorbing non-specific antibodies in the FTA-ABS test.

In our technique Reiter sonicate was used instead of sorbent. The FTA-ABS test was carried out only as a qualitative method. All positive sera were retested by a quantitative FTA method. All the tests were done in our laboratory, with the exception of the TPI tests which were carried out at the Białystok Venereal Diseases Research Laboratory and partially at the Venereal Diseases Research Laboratory in Wroclaw.

\section{Results}

TPHA results in 600 presumed healthy persons (Table I) Of the 600 probably healthy persons, a positive or doubtful TPHA result was obtained in six. There was nothing in the clinical findings or history to indicate syphilis in four of these cases $(0.66$ per cent. of the total investigated). One teacher and one hospitalized patient who were each found to have positive TPHA and negative TPI and reagin test results, were noted in our files as having been treated for syphilis 25 and 18 years before respectively.

TABLE I TPHA test results in 600 persons presumed free of syphilis infection

\begin{tabular}{|c|c|c|c|}
\hline \multirow[b]{2}{*}{ Group tested } & \multirow[b]{2}{*}{ No. tested } & \multicolumn{2}{|c|}{ Positive results } \\
\hline & & Non-specific & Specific \\
\hline $\begin{array}{l}\text { Pregnant women } \\
\text { Schoolgirls } \\
\text { (aged 16-18 years) }\end{array}$ & $\begin{array}{r}140 \\
70\end{array}$ & $2^{\mathrm{a}}$ & \\
\hline $\begin{array}{l}\text { Male conscripts } \\
\text { (from rural areas, } \\
\text { aged } 19 \text { years) }\end{array}$ & 150 & & \\
\hline $\begin{array}{l}\text { Persons of both } \\
\text { sexes tested } \\
\text { routinely (teachers } \\
\text { aged } 25-60 \text { years) }\end{array}$ & 140 & & $1^{b}$ \\
\hline $\begin{array}{l}\text { Hospitalized } \\
\text { patients (married } \\
\text { aged over } 50 \text { years) }\end{array}$ & 100 & 2 & $1^{\mathrm{b}}$ \\
\hline Total & 600 & 4 & 2 \\
\hline
\end{tabular}

The results were doubtful in these two patients

one patient treated in 1948: TPHA ++ , VDRL $(-)$, TPI 0 per cent, FTA-ABS +; and the other treated in 1955: TPHA + +, VDRL (-) (VDRL repeat test \pm ), TPI 0 per cent, FTA-ABS +

TPHA results in 130 presumed biologically false positive reactors (Table II, overleaf)

Among the 130 presumed BFP reactors, five $(3 \cdot 8$ per cent.) had non-specific positive TPHA test results. 
Three of these five gave doubtful TPHA results and the remaining two were strongly positive. In two other cases with positive TPHA and reagin tests but negative TPI tests, epidemiological evidence and repeat FTA-ABS tests revealed that the patients had previously been infected with syphilis.

\section{TABLE II TPHA results in 130 BFP reactors}

\begin{tabular}{|c|c|c|c|}
\hline \multirow[b]{2}{*}{ Group tested } & \multirow[b]{2}{*}{ No. tested } & \multicolumn{2}{|c|}{ Positive results } \\
\hline & & Non-specific & Spictfic \\
\hline BFP reactors & 130 & $5^{\mathrm{a}}$ & $2^{b}$ \\
\hline
\end{tabular}

TPHA results in 270 untreated syphilitics tested at various stages of infection (Table III)

In primary syphilis the sensitivity of the TPHA is lower than that of the FTA-ABS test. Sometimes the TPHA test can even give a negative result despite a positive VDRL test. The TPHA was positive in 53.3 per cent. of VDRL negative cases and in 85.7 per cent. of VDRL positive cases.

In the secondary stage of syphilis, the TPHA test, like the TPI and FTA-ABS tests, was positive in all the 41 cases. All the cases were strongly reactive in the FTA-ABS test and all but one in the TPHA test. The TPI test was doubtful or weakly reactive in seven of the 41 cases.

Two of the early latent cases gave a weakly positive TPHA test result and the remaining forty were strongly positive by this test. The FTA-ABS test results were strongly positive in 41 cases and weakly positive in only one. The TPI test was found to be considerably less sensitive during the period of early latent syphilis, being negative in three cases, doubtful or weakly positive in seven, and positive in the remaining 32 .

Of the 100 cases of late latent syphilis, the majority of which were tested 10 to 30 years after infection, the TPHA test was negative in only one case, weakly positive in seven, and strongly positive in the remaining 92. The FTA-ABS test showed a tendency to spontaneous seroreversal, manifested in weakly positive fluorescence of the borderline type, which was found in as many as $\mathbf{4 5}$ cases in this group. An even more marked tendency to seroreversal was observed in the TPI test results; these were negative in twelve cases, weakly positive or doubtful in 65 , and strongly positive in only 23.

In the group of thirty patients with late symptomatic syphilis, the TPHA test was weakly positive in one case and strongly positive in 29. The FTA-ABS test was weakly positive in three cases and strongly positive in the remaining 27 . In three cases the TPI test was negative, but in all cases of active neurosyphilis all three of the treponemal tests gave positive results.

TPHA results in 200 treated syphilitics (Table IV) Of the ten patients treated during the incubation period, five were included in our series because they were FTA-ABS reactive 3 to 6 months after prophylactic treatment. Of these, four were also TPHA reactive and one was found to have traces of immobilisins ( 21 per cent. specific immobilization). Of the five other cases tested after prophylactic treatment, only one was FTA-ABS and TPHA positive. The VDRL test was negative in all ten cases.

Of the seventy cases treated for primary or secondary syphilis, the TPHA test was negative in

TABLE III TPHA, FTA-ABS, and TPI test results in 270 patients tested at various stages of untreated treponemal infection

\begin{tabular}{|c|c|c|c|c|c|c|c|c|c|c|c|c|c|}
\hline \multirow{3}{*}{ Stage of syphilis } & \multirow{3}{*}{$\begin{array}{l}\text { No. } \\
\text { tested }\end{array}$} & \multicolumn{4}{|c|}{$T P H A^{\mathrm{a}}$} & \multicolumn{4}{|c|}{$F T A-A B S^{b}$} & \multicolumn{4}{|c|}{$T P I^{\circ}$} \\
\hline & & \multirow[t]{2}{*}{+} & \multirow[t]{2}{*}{++} & \multirow{2}{*}{$\begin{array}{l}\text { Total } \\
\text { reactive } \\
\text { No. }\end{array}$} & \multirow[b]{2}{*}{ Per cent. } & \multirow[t]{2}{*}{+} & \multirow[t]{2}{*}{$\geqq++$} & \multicolumn{2}{|c|}{$\begin{array}{l}\text { Total } \\
\text { reactive }\end{array}$} & \multirow[t]{2}{*}{+} & \multirow[t]{2}{*}{++} & \multicolumn{2}{|c|}{$\begin{array}{l}\text { Total } \\
\text { reactive }\end{array}$} \\
\hline & & & & & & & & No. & Per cent. & & & No. & Per cent. \\
\hline $\begin{array}{l}\text { Primary VDRL } \\
\text { negative } \\
\text { Primary VDRL }\end{array}$ & 15 & 5 & 3 & 8 & $53 \cdot 3$ & 4 & 11 & 15 & 100 & 0 & 0 & 0 & 0 \\
\hline $\begin{array}{l}\text { positive } \\
\text { Secondary } \\
\text { Early latent (first } 2 \text { yrs }\end{array}$ & $\begin{array}{l}42 \\
41\end{array}$ & $\begin{array}{r}15 \\
1\end{array}$ & $\begin{array}{l}21 \\
40\end{array}$ & $\begin{array}{l}36 \\
41\end{array}$ & $\begin{array}{l}85 \cdot 7 \\
100\end{array}$ & $\begin{array}{l}1 \\
0\end{array}$ & $\begin{array}{l}41 \\
41\end{array}$ & $\begin{array}{l}42 \\
41\end{array}$ & $\begin{array}{l}100 \\
100\end{array}$ & $\begin{array}{l}9 \\
7\end{array}$ & $\begin{array}{l}14 \\
34\end{array}$ & $\begin{array}{l}23 \\
41\end{array}$ & $\begin{array}{l}54 \cdot 8 \\
100\end{array}$ \\
\hline $\begin{array}{l}\text { of infection) } \\
\text { Late latent } \\
\text { Late symptomatic }\end{array}$ & $\begin{array}{r}42 \\
100 \\
30\end{array}$ & $\begin{array}{l}2 \\
7 \\
1\end{array}$ & $\begin{array}{l}40 \\
92 \\
29\end{array}$ & $\begin{array}{l}42 \\
99 \\
30\end{array}$ & $\begin{array}{l}100 \\
99 \cdot 0 \\
100\end{array}$ & $\begin{array}{r}1 \\
45 \\
3\end{array}$ & $\begin{array}{l}41 \\
54 \\
27\end{array}$ & $\begin{array}{l}42 \\
99 \\
30\end{array}$ & $\begin{array}{l}100 \\
99 \cdot 0 \\
100\end{array}$ & $\begin{array}{r}7 \\
65 \\
0\end{array}$ & $\begin{array}{l}32 \\
23 \\
27\end{array}$ & $\begin{array}{l}39 \\
88 \\
27\end{array}$ & $\begin{array}{l}92 \cdot 8 \\
88 \cdot 0 \\
90 \cdot 0\end{array}$ \\
\hline
\end{tabular}

TPHA + denotes weakly positive reaction only at a dilution of 1-80

bFTA-ABS + denotes weak fluorescence reported as borderline result

'TPI + denotes weak reactivity (20 to 80 per cent. specific immobilization)

TPI ++ denotes positive result ( $>80$ per cent. specific immobilization) 
TABLE IV TPHA, FTA, and TPI results in 200 patients tested after treatment

\begin{tabular}{|c|c|c|c|c|c|c|c|c|c|c|c|c|c|}
\hline \multirow[b]{2}{*}{ Stage of syphilis } & \multirow[b]{2}{*}{$\begin{array}{l}\text { No. } \\
\text { tested }\end{array}$} & \multicolumn{4}{|c|}{$T P H A^{\mathrm{a}}$} & \multicolumn{4}{|c|}{ FTA-titre } & \multicolumn{4}{|c|}{$T P I^{\mathrm{b}}$} \\
\hline & & + & ++ & \multicolumn{2}{|c|}{$\begin{array}{l}\text { Total } \\
\text { reactive }\end{array}$} & $\leqq 450$ & $>450$ & \multicolumn{2}{|c|}{$\begin{array}{l}\text { Total } \\
\text { reactive }\end{array}$} & + & ++ & \multicolumn{2}{|c|}{$\begin{array}{l}\text { Total } \\
\text { reactive }\end{array}$} \\
\hline $\begin{array}{l}\text { Incubation period } \\
\text { (prophylactic treatment) }\end{array}$ & 10 & 3 & 2 & 5 & $50 \cdot 0$ & 1 & 5 & 6 & 60 & 1 & 0 & 1 & 10 \\
\hline Primary & 30 & 9 & 20 & 29 & $96 \cdot 6$ & 23 & 3 & 26 & $86 \cdot 6$ & 7 & 6 & 13 & $43 \cdot 3$ \\
\hline Late latent & 50 & 5 & 45 & 50 & 100 & 17 & 33 & 50 & 100 & 14 & 29 & 43 & $86 \cdot 0$ \\
\hline Late symptomatic & 40 & 1 & 39 & 40 & 100 & 10 & 30 & 40 & 100 & 5 & 34 & 39 & $97 \cdot 5$ \\
\hline
\end{tabular}

aTPHA + denotes weakly positive reaction only at dilution of 1-80

bTPI + denotes weak reactivity ( 20 to 80 per cent. specific immobilization)

TPI ++ denotes positive result ( $>80$ per cent. specific immobilization)

only one case treated for primary syphilis, weakly positive in nine other cases of primary syphilis, and strongly positive in the remaining sixty. The FTAABS test was negative in only four of these seventy cases, but in 42 the FTA titre was low, not exceeding $1 / 450$. The TPI test was completely negative in thirty sera from this group and weakly reactive in nineteen.

Of the thirty patients treated during the early latent stage, the TPHA test was negative in one, weakly reactive in one other, and strongly positive in the remianing 28. The FTA-ABS test was also positive in 29 cases, but in eleven the FTA titre was low $(\leqq 1 / 450)$. The TPI test was negative in eleven cases and only weakly reactive in four.

The TPHA test remained strongly positive in 84 and was weakly positive in only six of ninety patients treated during the late stage of syphilis. The FTAABS was also positive in all these cases but the FTA titre was low in 27. The TPI test was found to have considerably lower sensitivity in the treated late syphilis patients, since in eight cases it was completely negative and in nineteen doubtful or weakly reactive.

TPHA results in a group of 200 problem sera (Table V) This group consisted of 200 sera in which there was disagreement between the TPI and FTA-ABS results or doubtful TPI or borderline FTA-ABS results.

Among 51 sera which were TPI non-reactive and gave a weak fluorescence of the borderline type making it particularly difficult to interpret the specificity of the FTA-ABS results, the TPHA test was positive in forty. In 32 sera with positive TPHA results, reagin antibodies were also found. The demonstration of three types of antibody
TABLE V TPHA test results in a group of 200 problem sera

\begin{tabular}{|c|c|c|c|}
\hline \multirow[b]{2}{*}{$T P I$ and $F T A-A B S$ results } & \multicolumn{2}{|c|}{ TPHA result } & \multirow[b]{2}{*}{ Total } \\
\hline & Positive & Negative & \\
\hline $\begin{array}{l}\text { TPI }- \text { FTA-ABS } \pm \\
\text { TPI }- \text { FTA-ABS }++ \\
\text { TPI } \pm \text {; FTA-ABS } \pm \\
\text { TPI } \pm \text {; FTA-ABS }++\end{array}$ & $\begin{array}{l}40^{\mathrm{a}} \\
33^{\mathrm{b}} \\
67 \\
43\end{array}$ & $\begin{array}{c}11^{\mathrm{c}} \\
2 \\
4\end{array}$ & $\begin{array}{l}51 \\
35 \\
71 \\
43\end{array}$ \\
\hline Total & 183 & 17 & 200 \\
\hline
\end{tabular}

${ }^{2}$ VDRL + in 32 cases

In fifteen cases ( 8 VDRL + and 7 VDRL - ) the case history also indicated infection

bVDRL + found in 21 cases

In 22 cases (11 VDRL + and 11 VDRL -) the case history also indicated infection

cIn seven cases tests repeated several times did not reveal traces of fluorescence

characteristic of treponemal infection was an important argument in favour of syphilis. Of these 32 TPHA, FTA-ABS, and VDRL reactive cases, eight also had historical and clinical evidence highly indicative of syphilis. Infection of the consort was established in two cases, in three further cases there was clinical evidence suggestive of late syphilis, and three patients had previously received large doses of penicillin for gonorrhoea during a period of high prevalence of syphilis. Of the eight cases reactive in the TPHA and FTA-ABS, but in which both the reagin and TPI test results were negative, the epidemiological data in seven were very highly indicative of syphilis. Infection of the consort was established in four cases and three patients had previously received prophylactic treatment.

Of the group of 35 TPI non-reactive and FTAABS strongly reactive sera, 33 were also positive in the TPHA test. The additional data indicated a high probability of syphilis in all but one of the 33 TPHA 
reactive cases. Reagin antibodies were detected in 21 of these 33 TPHA reactive sera, and in eleven of the same 21 cases the case-history and clinical and epidemiological data indicated the probability of syphilis infection. Similar assessment also made this seem likely in eleven out of twelve cases in which both the TPI and reagin tests were negative.

Of the 114 cases in which the TPI results were difficult to interpret because of their very weak and poorly reproducible reactivity, 43 sera were positive in the FTA-ABS test and weak fluorescence of the borderline type was obtained in the remaining 71 . The TPHA test was positive in all but four sera of both these groups, giving additional support to the diagnosis of syphilis in these cases in which syphilis infection already seemed highly probable.

A negative TPHA result was obtained in seventeen of the 200 problem sera, thirteen of which were TPI non-reactive. Of eleven cases with negative TPI results and borderline fluorescence, seven had negative results in two or more repeat FTA-ABS tests on the same or another serum specimen, showing that the very weak fluorescence previously observed was due to incomplete absorption of group antibodies with Reiter treponeme sonicate. In the remaining four of these eleven cases with nonreactive TPHA tests the clinical or epidemiological data indicated a strong possibility of syphilis infection; two cases were those of patients with treated very early syphilis and in two epidemiological evidence suggested spontaneous seroreversal of the TPHA while persistent trace amounts of fluorescent antibodies caused borderline fluorescence. As regards the remaining six problem sera with a negative TPHA test result, no additional data were obtained which would enable us to come to any diagnostic decision.

\section{Discussion}

Our investigations on the sensitivity of the TPHA test have confirmed the observations made by other authors (Logan and Cox, 1970; West and Pagano, 1972; O'Neill and others, 1973) that during the primary stage of syphilis the TPHA test is less sensitive than the FTA-ABS test. In our previous reports (Lesiński and Krach-Karczmarczyk, 1971, 1973a) we have shown that in primary syphilis the antibodies detected by the TPHA test are detected somewhat later than the reagin antibodies. In the present study we found the TPHA test to be reactive in 53 per cent. of the VDRL negative and 86 per cent. of the VDRL positive cases of primary syphilis. The sensitivity of the TPHA test in this period of infection is certainly lower than that of the FTA-ABS test but slightly higher than that of the VDRL test.
In the secondary stage of syphilis the TPHA test is equal in sensitivity to the FTA-ABS test.

Our investigations have shown quite clearly that in the later stages of untreated infection the TPHA test has very little tendency towards spontaneous seroreversal and its sensitivity is not only much superior to that of the TPI test but also greater than that of the FTA-ABS test in that the latter gave many more weakly positive tests than the TPHA test.

The findings of the investigations of 200 sera from treated syphilitics show that, with few exceptions, the TPHA test remains positive also after treatment. Even in cases of early syphilis, seroreversal to negative after treatment occurs much less frequently in the TPHA than in the TPI test, and even less often than in the FTA-ABS test. In our cases of late syphilis the TPHA test remained positive, usually strongly so, despite intensive treatment.

The results obtained from the group of 600 sera from persons without any symptoms and probably free from syphilitic infection seem to confirm the views of Luger and Spendlingwimmer (1973), West and Pagano (1972), Johnston (1972), O'Neill and others (1973), and Sequeira and Eldridge (1973) that non-specific TPHA results are very rare in healthy persons. The frequency of non-specific haemagglutination test results $(0.66$ per cent.) was similar to that observed in the investigations of the above mentioned authors. We also found in this group two cases of previous syphilis infection with negative TPI and VDRL tests and with doubtful FTA-ABS test results.

In the group of 130 sera from BFP reactors, the frequency of non-specific TPHA results was 3.8 per cent. Among the 130 presumed BFP reactors, however, were two patients with negative TPI tests who were found to be infected with syphilis on the basis of epidemiological data and TPHA results, and repeat FTA-ABS test results. The fact that, in the investigations carried out to date on the specificity of the TPHA test, historical and epidemiological data have not been sufficiently taken into account, has resulted in an increase in the percentage of presumed non-specific TPHA results.

The number of sera from BFP reactors covered in our investigations was too small to enable us to question the results of the studies of Garner and others (1973) on the possibility of a comparatively frequent occurrence of non-specific results in certain groups of BFP reactors. Unpublished studies which we have recently begun on the specificity of the TPHA test in patients suffering from autoimmune diseases also seem to indicate that in certain pathological conditions the possibility of non-specific 
TPHA results should be taken into account. All our investigations on the specificity of the TPHA test have proved that it is definitely inferior in specificity to the TPI test. This is in agreement with the clinical observations of the majority of authors and the experimental studies of Cox and others (1969) and of Ohta (1971). The specificity of the new method would seem to correspond to the specificity of the FTA-ABS test, but in certain pathological states which cause BFP reactions with reagin tests, nonspecific results with the TPHA test occur more frequently than with the FTA-ABS test.

In view of the considerable, though not absolute, specificity of the TPHA test and particularly the high sensitivity of this method, we decided to investigate its value as a verification test for problem sera. A detailed analysis of our investigations on this group of sera has convinced us that this new treponemal test is an important, though not always decisive, criterion in the interpretation of problem sera. It is of particular value in cases of conflicting TPI and FTA-ABS results. In our opinion the test should be used in the verification examinations carried out by reference laboratories. Because of its marked sensitivity, the TPHA test is a valuable addition to the serological tests found to be most useful in late syphilis. Considerable specificity and extremely high sensitivity also make it suitable for use in screening procedures. It is possible that with advances in the automation of the TPHA test and a reduction in the production costs of the antigen, this test will replace the cardiolipin tests to a far wider extent than have the treponemal tests used to date. In certain categories of cases, however, positive TPHA results should be verified by the FTA-ABS test or the TPI test.

It should also be emphasized that, until the question of the behaviour of the TPHA test in various groups of BFP reactors is satisfactorily solved, the TPHA test should not be applied as the sole confirmatory test in the routine serodiagnosis of syphilis.

\section{Summary}

The TPHA test was carried out on 1,400 sera and the results compared with those of the FTA-ABS and TPI tests and in some cases with those of the VDRL test.

470 sera were from syphilitics, 600 from presumed healthy persons, and 130 from presumed BFP reactors, and 200 were problem sera, of which the majority had shown disagreement between the FTA-ABS and TPI results.

The investigations showed that, in the primary stage of syphilis the TPHA sensitivity is lower than that of the FTA-ABS test but slightly greater than that of the VDRL test. In the secondary stage of syphilis the sensitivity is equal to that of the FTAABS test. In the late stage of syphilis very little tendency to spontaneous reversal to negativity was noted in the TPHA test and its sensitivity is not only much higher than that of the TPI test but also higher than that of the FTA-ABS test.

In cases of treated primary or secondary syphilis, seroreversal of the TPHA test seldom occurs; this happened far less frequently than with the TPI test and slightly less often than with the FTA-ABS test. In cases of treated late syphilis, the TPHA test generally remained strongly positive.

The specificity of the TPHA is not absolute but corresponds to that of the FTA-ABS test. The problem of the possibility of non-specific results in certain groups of BFP reactors has not yet been adequately solved.

An analysis of the results of these serological tests and the entire clinical and epidemiological evidence in the group of problem sera showed that the TPHA test is an important criterion in the serological verification of problem sera as well as in the diagnosis of late syphilis. It is particularly valuable in cases where there is disagreement between the TPI and FTA-ABS test results.

With further automation of the method and a reduction in the cost of producing the antigen, the TPHA test may well replace the reagin tests in screening procedures.

Note

This investigation received financial support from the World Health Organization.

\section{References}

Cox, P., Logan, L., and Norins, L. (1969) Appl. Microbiol., 18, 485

Dixon, J., Grocholski, J., and Kadis, E. (1972) Canad. F. publ. Hlth, 63, 257

GaRnER, M., BaCkhouse, J., Daskalopoulos, G., and WALSH, J. (1972) Brit. F. vener. Dis., 48, 470

,,,----1 (1973) WHO working document WHO/VDT/RES/294

Johnston, N. (1972) Brit. f. vener. Dis., 48, 474

KRAFT, D., MORGENSTERN, M., RAFF, M., and SöltZSzöTs, J. (1973) Z. Haut u.-GeschlKr., 48, 221

Le ClaIR, R. (1971) f. infect. Dis., 123, 668

LestísKI, J. and KRACH-KaRCZMARCZYK, J. (1971) Paper presented to the Tenth Scientific Symposium of the Polish Venereology Society, Warsaw

- - - (1973a) Przegl. Derm., 60, 41

, - (1973b) WHO working document WHO/ VDT/RES/298 
—, MIEDzIŃskI, F., and TowPIK, J. (1970) 'Współczesna Syfilidologia' (Modern Syphilology). PZWL (Polish State Medical Edition), Warsaw

Logan, L., and Cox, P. (1970) Amer.F. clin. Path., 53, 163

LUGER, A., and SPENDLINGWimmer, I. (1973) Brit. $\mathcal{f}$. vener. Dis., 49, 181

ManikowsKa-LesiŃsKa, W. (1973a) Przegl. Derm., 60, 45

- (1973b) Paper presented to the XII Scientific Symposium of the Polish Venereology Society, Bytom, Poland

OHTA, Y. (1971) WHO working document WHO/VDT/ RES/254

O'NeILL, P., WARNER, R., and NICOL, C. (1973) Brit. F. vener. Dis., 49, 427

Paris-Hamelin, A., Catalan, F., and Vaisman, A. (1970) Bull. Soc. franç. Derm., 77, 474

RATHIEV, T. (1965) WHO working document WHO/ VDT/RES/77

SequRira, P. J. L., and Eldridge, A. (1973) Brit. $\mathcal{F}$. vener. Dis., 49, 242

Tomizawa, T., and Kasamatsu, S. (1966) fap. f. med. Sci. Biol., 19, 305

,-- , and YAMAYA, S. (1969) Ibid., 22, 341

USPHS (1964) 'Manual of Tests for Syphilis'. United States Government Printing Office, Washington, D.C.

- (1969) 'Manual of Tests for Syphilis'. United States Government Printing Office, Washington, D.C.

West, B., and Pagano, D. (1972) HSMHA Hlth Rep., 87, 93

\section{Spécificité, sensibilité et valeur diagnostique du} test TPHA

\section{SOMMAIRE}

Le TPHA fut effectué sur 1.400 sérums et les résultats sont comparés avec ceux du FTA-ABS et du TPI ainsi que, dans quelques cas, avec ceux du VDRL.
470 sérums provenaient de sujets syphilitiques, 600 de sujets présumés sains et 130 de sujets présumés faussement positifs (BFP) et 200 posaient des problèmes sérologiques parmi lesquels la majorité montrait une discordance entre les résultats du FTA-ABS et du TPI.

Ces recherches montrèrent que, au stade primaire de la syphilis, la sensibilité du TPHA est moindre que celle du FTA-ABS mais légèrement plus grande que celle du VDRL. Au stade secondaire de la syphilis, la sensibilité fut équivalente à celle de l'épreuve FTA-ABS. Au stade tardif de la syphilis, il fut noté une très petite tendance du TPHA au retour spontané à la négativité et sa sensibilité n'est pas seulement beaucoup plus élevée que celle du TPI mais également plus élevée que celle du FTA-ABS.

Dans les cas de syphilis primaire ou secondaire traités, on observe rarement le retour à la négativité du TPHA; ceci survint beaucoup moins fréquemment qu'avec le TPI et un peu moins souvent qu'avec le FTA-ABS. Dans les cas de syphilis tradive traités, le TPHA resta généralement fortement positif.

La spécificité du TPHAn'est pas absolue mais correspond à celle du FTA-ABS. La question de la possibilité de résultats non spécifiques dans certains groupes de réacteurs BFP n'a pas, jusqu'ici, été résolue d'une manière satisfaisant.

Une analyse des résultats de ces épreuves sérologiques ainsi que de l'ensemble des preuves cliniques et épidémiologiques dans le groupe des sérums posant des problèmes a montré que l'épreuve TPHA est un critère important, aussi bien pour l'étude des sérums posant des problèmes que pour le diagnostic des cas de syphilis tardive. Ce test a une valeur particulière lorsqu'il y a désaccord entre les résultats du TPI et de l'épreuve FTA-ABS.

Avec l'automation ultérieure de la méthode, et avec une diminution du coût de production de l'antigène, l'épreuve TPHA pourra bien remplacer les épreuves de réagine dans les dispositifs de dépistage. 